\title{
SOĞUK SAVAŞ SONRASI RUSYA FEDERASYONU İÇ GÜVENLİK BİRIMLERİ
}

\author{
Ahmet Burak IÇEN*
}

Öz

Bu makalede Soğuk Savaş sonrası modern Rusya'nın iç güvenlik aktörleri ayrı ayrı incelenmiş, yapısal ve kurumsal özellikleri haricinde daha anlaşılabilir olması adına ülkemiz muadil kurumlarıyla karşılaştırmaları yapılmıştır. Rusya Federasyonu kapladĭ̆ı milyonlarca kilometrekare toprağı ve bu topraklar içerisinde yaşayan çok çeşitli halkları ile zor ve büyük bir coğrafyada iç güvenlik ve iç asayişi sağlamaya çalışmaktadır. Böylesine farklı halkları bir arada geniş bir coğrafyada barındırmak örgütsel ve mali olarak oldukça zor bir iş haline gelmiş, soğuk savaş sonrası Sovyetler Birliğinin ylkılması üzerine temelinden sarsılan düzen, yeni bir devlet anlayışı içerisinde yapılanma zorunluluğu getirmiştir. İç karışıklıklar ve ekonomik buhranlar yapılanmanın yavaşlamasına neden olmuş, iç güvenlik sorunu uzun yıllar boyunca Rusya'nın en önemli sorunu olmuştur. Putin dönemine kadar yeniden yapılanma ile rol model kapsamında yetersiz kalınmıs ve Sovyetler geleneği hissedilmeye devam etmiştir. Ancak Putin dönemi ile Çarlık Rusya'sı devlet düzeni incelenmiş ve Çarlık Rusyast-Sovyetler sentezi ile kendine özgü bir iç güvenlik anlayışı ve bu anlayış üzerine yapılanan kurumlar ortaya çıkmıştır. Makalede, yeniden yapılanan iç güvenlik organlarının yapısal, işlevsel yönleri ele alınmış, Türkiye'deki muadilleri ile karşılaştırılması amaçlanmıştır.

Anahtar Kelimeler: Rusya Federasyonu, Putin, iç güvenlik, MVD, FSB, ROSGVARDIYA.

\section{INTERNAL SECURITY UNITS THE RUSSIAN FEDERATION AFTER THE COLD WAR}

\begin{abstract}
In this article, the internal security actors of modern Russia after the Cold War were examined separately and compared with our country's counterparts besides their structural and institutional characteristics in order to be more understandable. The Russian Federation seeks to ensure internal security and internal order in a difficult and large geography with millions of square kilometers of land covered by it and a wide range of people living within it. Having such a diverse geography together in a wide geography has become very difficult both organizationally and financially and After the collapse of the Soviet Union in the aftermath of the Cold War, the system, which was undermined by the collapse of the Soviet Union, brought about the necessity of structuring within a new state domestic disturbances and economic crisis have slowed down the structure, and the problem of internal security has been Russia's most important problem for many years. Until the Putin period, the restructuring process was insufficient within the context of role model and the Soviet tradition continued to be felt. However, the Putin period and the state system of the Tsarist Russia were examined and a distinctive understanding of domestic security and institutions built on this understanding have emerged with the synthesis of the Tsarist Russia-Soviet. In this article, structural and functional aspects of the restructured internal security organs have been addressed and are intended to be compared with their counterparts in Turkey.
\end{abstract}

Keywords: Russian Federation, Putin, Internal Security, MVD, FSB, ROSGVARDIYA.

\footnotetext{
* Polis Akademisi Güvenlik Bilimleri Enstitüsü İstihbarat Araştırmaları Bölümü Yüksek Lisans Öğrencisi, ahmetburakicen@yahoo.com.tr, https://orcid.org/0000-0003-4283-1438
} 


\section{GíRIŞ}

Rusya Federasyonu, özerk cumhuriyetlerden ve bölgesel yönetim parçalarından oluşmaktadır. Sayısal olarak 8 federal ana bölge, 22 özerk cumhuriyet, 9 eyalet, 46 bölge, 4 özerk bölge,1 özerk alan ve 3 ana şehirden oluşmaktadır (Rusya Federasyonu Anayasası, 1993). Yönetimsel olarak küçük bölgeler aşağıdan başlayarak statüleri bağlamında birer zincir halinde Moskova'daki merkeze bağlıdırlar. Özerk cumhuriyetlerde, federal meclis ve bakanlıklar dışında, devlet başkanları ve meclisler seçim sistemiyle belirlenmektedir. 2010 y1lı sonunda, özerk cumhuriyet liderlerinin "devlet başkanı" unvanı Dimitry Medvedev'in talimatıyla hazırlanan kanun değişikliği ile "devlet başı” olarak değiştirilmiştir (Zakon ot 06.10.1999 N 184-F3, 2016). Rusya, anayasal olarak federal yönetimi benimsemiş olup birçok özerk cumhuriyeti ve farklı halkı barındırmaktadır. Soğuk Savaş dönemi Sovyetlerinden miras kalan, pek çok özerk yönetimi bünyesinde bulunduran Rusya'nın federal yönetimle ilgili bu kabulü, geniş bir coğrafyada egemen olan Çarlık Rusyası politikalarına doğru bir eksen kaymasının adımları olarak yorumlanmıştır.

8 federal ana bölgeye ayrılan Rusya Federasyonu, ülkemizdeki gibi coğrafi vb. amaçlı olarak böyle bir sınıflandırmaya gitmemiştir, bunun başka sebepleri de bulunmaktadır. Yönetim amaçlı olarak ayrılan federal bölgelere birer lider atanmış ve konumlarına göre cumhuriyet, eyalet, bölge ya da özerk bölgeler federal bölgelere bağlanmıştır. Bu bağlanma hiyerarşik bir düzene göre yapılmıştır. Yerel bölgeler federal bölgelere, son noktasında ise Moskova'da bulunan federal yönetim merkezlerine bağlanmıştır. Örneğin, özerk cumhuriyet başkanını atadığı bir içişleri bakanı (MVD), federal içişleri generaline, general ise doğrudan içişleri bakanına bağlıdır. Söz konusu yönetimsel işleyiş diğer birçok devlet dairelerinde de bu şekildedir.

Soğuk Savaş zamanı ABD ile girişilen silahlanma ve hegemonya yarışı Sovyet ekonomisine ağır darbeler vurmuştur. Bu yarışın sonunda Sovyetlerin yıkılması derin ekonomik ve toplumsal sorunların doğmasına sebep olmuştur. Demir Perde'nin yıkılması ile Sovyet vatandaşları dünya ile tanışmıştır. Ancak bu tanışma bazı sorunları da beraberinde getirmiştir. Rus para birimi olan "ruble"nin dünya üzerinde hiçbir geçerliliği ve değerinin olmaması, yabancı ülke mallarının içeri girişi ve halkın hiç alışkın olmadığı serbest piyasa anlayışı rüşvet ve yolsuzluk gibi günümüze kadar devam eden sorunlar sarmalına dönüşmüştür. $\mathrm{Bu}$ sorunların çözümüne yönelik olarak yolsuzluk ve rüşvetle mücadele kanunu (Zakon ot 25.12.2008 N273-F3, 2008) çıkarılmış, memurların maaş ve sosyal imkânlarının 
sürekli iyileştirilmesine yönelik çalışmalar yapılmıştır. Ancak devletin yüksek mertebedeki memurlarının adının karıştığı rüşvet olayları, alınan önlemlerin ve diğer iyileştirme çalışmalarının rüşvetle mücadelede yetersiz kaldığının göstergesidir ${ }^{1}$.

\section{RUSYA FEDERASYONU İÇIŞLERİ BAKANLIĞI (MVD)}

Rusya Federasyonu İçişleri Bakanlığı (MVD) federal yürütme organıdır. İçişleri ve diğer ilgili organlar MVD başlığı altında toplanmaktadır (Andreva, 2011: 299). Kurum ülke içerisindeki tüm asayiş ve adli vakalarından sorumludur. Türkiye Cumhuriyeti Emniyet Genel Müdürlüğü yapısı itibarıla Türkiye Cumhuriyeti İçişleri Bakanlığına bağlıdır, ancak kendine özgü bir kurumsal yapıya sahiptir. Rusya Federasyonu Polis Teşkilatı, Türkiye Cumhuriyeti Emniyet Genel Müdürlüğü yapısından farklı olarak, İçişleri Bakanlığı bünyesinde ayrı bir kurumsal yapıya sahip değildir. Rus polis teşkilatında içişleri bakanı, en alt kademedeki personelden en üstte yer alan bakana kadar, bir polis teşkilatı yapısıyla düzenlenmiş, ayrı bir kurumsal kimlik arayışı içinde bulunulmamıştır. Yönetim kadrolarında istisnai olarak sivil görevlendirmeler bulunsa da geçmiş görevlendirmeler de göz önünde bulundurulduğunda, büyük ölçüde askerî bir yapıya sahip olduğu görülür ${ }^{2}$. Teşkilatın rütbeleri askerî sisteme göre olup "uzman onbaşı"dan başlanarak sırası ile "general"e kadar devam etmektedir. Sivil bir bakan yerine, devlet geleneğine uygun olarak, polis teşkilatından bir general, devlet başkanı tarafından "bakan" olarak atanmaktadır. Federal yapısı itibarıyla 22 özerk cumhuriyeti bulunan Rusya Federasyonu'nun 22 özerk içişleri bakanı bulunmakta, bu bakanlar daha önce de belirtildiği gibi sırası ile federal bölge içişleri generaline ve federasyon içişleri bakanına bağlıdırlar. Yeniden Yapılanma (Perestroyka) ${ }^{3}$ hareketi ile Sovyet Sosyalist Cumhuriyetler Birliği (SSCB)'ne karşı başlayan halk ayaklanması Rusya Sovyet Federatif Sosyalist Cumhuriyeti'nin ilanı ile nihayete ermiş ve günümüz Rusya Federasyonu'nun temelleri atılmıştır. Yeniden Yapılanma hareketine kadar, Soğuk Savaş yıllarında 'Sovyet Polisi' adı altında çalışan polis teşkilatı, SSCB'nin rejim güvenliği ve muhaliflerin susturulmasına

\footnotetext{
${ }^{1}$ MVD Tümgenerali Aleksandr Bokov'un rüşvet suçu işleyerek tutuklanmasıyla ilgili haber için bk.: http://www.ntv.ru/novosti/217591/, (Erişim Tarihi:19.03.2017). Büyük rüşvet ya da yolsuzluk olaylarının haricinde yerel bölgelerde, taşrada rüşvet alıp vermenin günlük doğal bir olay haline geldiği tarafımızca da gözlemlenmiştir.

2 Askerî kaynaklı görevlendirmelere örnek olarak bk.: https://xn--blaew.xn-p1ai/mvd/Rukovodstvo/item/670535/, (Erişim Tarihi:18.03.2017)

31980 yılının ikinci yarısında başlayan ve 1991 yılında Rusya Sovyet Federatif Sosyalist Cumhuriyeti(RSFSC)'nin ilanına kadar 4 etap halinde devam eden, Sovyet rejimine karşı başlayan halk hareketidir.
} 
ağırlık vermiş, asli görevlerinden uzaklaşmıştır. 18 Nisan 1991 yılında RFSC Yüksek Konseyi'nin "Polisler Hakkında Kanun" kapsamında Sovyet Polisliği kaldırılmış (İstoriya MVD Rossii, 2000), kesin tanımlar ile kişisel, kamusal hak ve özgürlüklere değinilmiş ve bunların korunması yönünde maddeler eklenmiştir (Zakon ot 18.04.1991 N1026-1, 2010).

Polis teşkilatı daha önce "militsya" olarak anılırken polisin etkin olarak faaliyetlerinin kalitesinin arttırılması amacı ile 1 Mart 2011'de yürürlüğe giren "Polisler Hakkında Federal Kanun" ile tanım "politsya" olarak değiştirilmiştir (Zakon ot 07.02.2011 N3-F3, 2011). Polis memurlarına verilen "militsioner" tanımı Latincedeki "militia" köküne dayanmakla birlikte, Rus dilinde "militsya" aynı zamanda "Gönüllü Asker Takımı" ya da "Milli Milis Kuvveti" anlamına da gelmektedir (RİA NOVOSTİ, 2011). Rusya Polis Teşkilatı kendisine atfedilen "Sovyet-Komünist" tanımlamasından 2011'de sıyrılmış, 23 Mart 1917 yılında lağvedilip kendisinden alınan "polis" tanımlamasını geri almıştır. Söz konusu kanun sadece isim değişikliği değil, kurumun hantallaşan yapısının değiştirilmesi amacı da güdülmüştür. Yapısında $\% 20$ oranında küçülmeye gidilmiş, daha aktif ve işlevsel yapıya erişmesi sağlanmaya çalışılmıştır (Zakon ot 07.02.2011 № 3-F3, 2011).

\subsection{Dâhilî Ordu (Vnutrennie Voyska)}

MVD bünyesindeki Dâhili Ordu, polis kuvvetlerinin yanı sıra özel operasyonları ve yurtiçi diğer askerî operasyonları gerçekleştirmek gibi görevleri bulunan bir bölümdür. Personel kaynağı, zorunlu askerlik hizmeti yapan erler ya da sözleşmeli olarak bulunan profesyonel personeldir (Andreva, 2011: 313). Yapısal olarak ülkemizdeki Jandarma Genel Komutanlığı'na benzerlikleri bulunmakla birlikte kırsal alanda asayiş faaliyetleri yürütmeyip, genel veya özel operasyonlar çerçevesinde faaliyet göstermektedir (Andreva, 2011: 304). Mobil Özel Görev Birimleri (OMON) ve Vostok (Doğu) ya da Zapad (Batı) gibi özel ekiplerin bağlı olduğu gizli operasyonların yürütüldüğü bir birimdir.

Dâhilî Ordu, iç operasyonların yanı sıra Ukrayna Donbas'taki ayrılıkçıların eğitimi ve desteklenmesinde, Rusya'nın savaşa müdâhil olması ile OsetyaGürcistan savaşında direkt sıcak çatışmalarda görev almıştır. Söz konusu ordu, 5 Nisan 2016'da Rusya Federasyonu Başkanı'nın emriyle içişleri bakanlığından alınarak "Rusya Federasyonu Milli Muhafiz Ordusu Federal Hizmetleri'ne dönüştürülmüş, bünyesindeki özel amaçlı ekip ya da birlikler içişleri bakanlığından alınarak Milli Muhafız Ordusu altında toplanmıştır (Ukaz Prezidenta Rossiyskoy Federatsii № 157 ot 5 aprelya 2016, 2016). 


\subsection{Kazaklar (Rus Kazakları)}

Orta Asya'daki Türk kökenli Kazaklardan tamamen farklı olarak, Rus ve Osmanlı kaynaklarında Rus Kazakları olarak adlandırılmışlardır. Hristiyan olup Rus-Slav kökeninden gelmektedirler. Rus Kazakları, Osmanlı-Rus savaşlarında ve Çarlık Rusya'sının Kuzey Kafkasya'yı işgali sırasında aktif olarak Rus ordusunun içinde yer almışlardır (Tavkul, 2005: 71-96).

Çarlık Rusyası'nda ve sosyalist devrim sonrası Sovyetlerde Kazak Birliği olarak teşkilatlanan Rus Kazakları, Rusya Sovyet Federatif Sosyalist Cumhuriyeti (RSFSC)'nin kurulmasının ardından, Rus devleti içerisinde varlıklarını devam ettirmiştir. Ocak 1995'te Rusya Federasyonu Başkanının emri ile "Rusya Federasyonu'na Kayıtlı Kazaklar İçin Geçici Düzenlemeler" adı altında çıkarılan kanun ile doğrudan Rusya Federasyonu Başkanına bağlı Kazak birliği kurulmuştur (Ukaz Prezidenta Rossiyskoy Federatsii ot 09.08.1995 N835, 1995). 27 Ağustos 1996'da Kazak Koordinasyon Birliği kurulmuştur. 1998'de içişleri bakanının çıkardığı bir kararname ile genel olarak bakanlığın bir kolu olmaktan çıkarılan birlik, yerel yönetimlerin kanunlarına bırakılmış, yerel kanunlar izin verdiği ölçüde Kazak Birliklerinin kullanılmasının önü açılmıştır. Kazak Birlikleri tüm iç güvenlik birimlerinde kullanılmamakla birlikte, yerel kanunlarının izin verdiği bölgelerde (Kaliningrad, Stavrapol, Chelyabinsk vd. ) iç güvenliği sağlamak amaciyla polis kuvvetleriyle birlikte asayiş hizmeti vermektedir (Bykovskiy, 2002: 3-4). Ülkemiz koruculuk sistemine benzer bir tarzda çalışan sistem, taşra yerine şehir içi asayiş̧ faaliyetleri gerçekleştirmektedir. Çok uluslu yapısından dolayı milletlerarası ilişkileri, politikaları ve gerekli iyileştirmeleri uluslararası hukuka göre gerçekleştirmek amacı ile kurulmuş olan icra organı "Milletler Federal Ajansı", görev tanımlarında sık sık Kazakların rehabilitasyonu ve haklarına yer vermektedir (Milletler Federal Ajansı, 2015). Söz konusu görev tanımları dahi Rusya'nın bakış açısını yansıtmaktadır.

Kuzey Kafkas halklarının geleneksel kıyafetlerine benzer kıyafetleri ile günlük yaşamlarını sürdürüp, "Ataman" olarak adlandırdıkları yerel şeflerinin yönlendirmesi ve talimatları ile hareket etmektedirler. Zaman zaman gerek Rus basınında gerek Kazak Atamanlarının federal ya da yerel devlet görevlileri ile yaptı̆̆1 görüşmelerde, Kuzey Kafkasya özerk cumhuriyetlerinin asayiş hizmetlerinde Rus Kazaklarının asayiş hizmetlerine katılması gerekliliği vurgulanmaktadır. Bölgede yaşayanların tarihsel hatıraları ve tecrübeleri, gerek Kuzey Kafkasya asıllı devlet görevlileri gerek halk arasında rahatsızlığa neden 
olmaktadır ${ }^{4}$. Söz konusu rahatsızlıklar bugüne kadar bir iç çatışmaya neden olmamakla beraber, konunun ciddileşmesi ya da resmîleşmesi gibi bir durumda Kuzey Kafkasya cumhuriyetlerinde 1rksal bir çatışmaya dönüşme potansiyeli taşımaktadır.

\subsection{MVD'nin Bölümleri}

MVD‘nin merkezini Polis kuvvetleri oluşturmaktadır. Birimler; genel müdürlükler, daireler, müdürlükler ve merkezler olarak 4 ayrı bölümden oluşmaktadır (MVD ”Struktura Ministerstva", 2000) .

\subsubsection{Genel Müdürlükler}

- Karayolları Trafik Güvenliği Genel Müdürlüğü

- Toplumsal Güvenlik ve Rusya Federasyonu İcra Makamları Karşıllklı Koordinasyon Genel Müdürlüğü

- Aşırılıkla Mücadele Genel Müdürlüğü

- Öz Güvenlik Genel Müdürlüğü

- Ulaşım Genel Müdürlüğü

- Kriminal Genel Müdürlüğü

- Ticari Güvenlik ve Rüşvetle Mücadele Genel Müdürlüğü

- Göçmen Sorunları Genel Müdürlügü

- Uyuşturucu Kontrol Genel Müdürlüğü

\subsubsection{Daireler}

- Sorgu Dairesi

- Kamu hizmeti ve personel dairesi

- Vatandaş ve Organizasyon İş ve Yönetimi Müracaat Dairesi

- Bilgi Teknolojisi, İletişim ve Bilgi Koruma Dairesi

- Finansal-Ekonomik Politika ve Sosyal Güvence Dairesi

- Kontrat ve Hukuk Dairesi

- Organizasyon-Analiz Dairesi

\subsubsection{Müdürlükler}

- Rusya MVD, "K” Müdürlüğü (Siber suçlarla mücadele)

- Devlet Korumasına Tabi Kişilerin Emniyeti Müdürlüğü

- Sivil Toplum Kuruluşları ve Medya ile İşbirliği Müdürlüğü

- Uluslararası ve Büyük Spor Faaliyetleri Emniyeti Müdürlügü

- Örgütsel-Personel Müdürlüğü

- Kontrol-Denetim Müdürlüğü

${ }^{4}$ Konuyla ilgili örnek bir haber için bk.: http://kavpolit.com/articles/kazachij_patrul_dlja_adygei19027/, (Erişim Tarihi: 19.03.2017) 
- İlk Soruş̧turma Organizasyonu Müdürlüğü

- Operasyon Müdürlüğü

- İnterpol Milli Merkez Bürosu

- Özel Amaçlı Birlik Faaliyetleri ve Havacılık Müdürlügü

\subsubsection{Merkezler}

- MVD Rusya Akademisi

- Tüm Rusya MVD Personel Geliştirme Enstitüsü

- Tüm Rusya Bilim-Araştırma Enstitüsü

- Ana Bilgi-Analiz Merkezi

- Yönetimsel-İktisadi ve Ulaşım Temini Ana Merkezi

- İletişim ve Bilgi Güvenliği Ana Merkezi

- MVD Rusya Özel Yükler Nakliyesi Ana Merkezi

- 'Özel Teknikler ve İletişim' Bilimsel-Üretim Birliği

- MVD Rusya Yayınlar Birliği

- MVD Rusya Köpek Eğitim Merkezi

- MVD Rusya Meteoroloji Merkezi

- MVD Rusya Yol Emniyetinin Sağlanması Alanında Özel Görev Merkezi

- Bilirkişi-Kriminal Merkezi

- MVD Rusya Sosyal Çalışmalar Merkezi

- MVD Rusya Yol Emniyeti Sorunu Bilim-Araştırma Merkezi

\subsection{MVD'de Eğitim ve Personel Alımı}

Polis alımlarımda kişinin cinsiyeti, milliyeti, dini vs. bakılmaksızın Rus diline kişisel ve mesleki yeterlilik seviyesinde hâkim, 18 yaşını dolduran her vatandaş içişleri hizmetinde çalışabilir, içişleri hizmeti için üst sınır 35 yaştır (MVD "Priem na sluzhbu“, 2000).

MVD profesyonel kadrolar yetiştirmek adına 5 akademi, 15 enstitü, 19 üniversite şubesi ve 6 Suvorov askerî lisesi ile eğitim ve yükseköğretim vermektedir. Hâlihazırda 80 bin personele aynı anda eğitim verilirken, 10 bin kişi de akademik eğitim almaktadır. Personelden 3039 kişi yüksek lisans, 629 kişi doktora eğitimi almakta, 1249 kişi doçentlik, 444 kişi ise profesörlük unvanı için çalışma yapmaktadır (MVD Obrazovatelnaya sistema”, 2000).

\section{FEDERAL EMNIYET HIZMETLERİ (FSB)}

Soğuk savaş yıllarında isminden sürekli bahsettiren ve rüştünü ispatlamış bir istihbarat örgütü olan Devlet Emniyet Komitesi (KGB) ,Soğuk Savaşın akabinde, tüm devlet dairelerinin yaşadığ gibi, değişimden etkilenmiştir. 1991 - 1995 yılları arasında 4 kez yapısal ve ismen/şeklen değişime uğrayan kurum, Boris Yeltsin'in 3 
Nisan 1995'te imzaladığ1 "Rusya Federasyonu Federal Emniyet Hizmetleri Hakkında" kanun ile Federal Emniyet Hizmetleri'ne (FSB) dönüştürülmüştür (Zakon ot 03.04.1995 N40-F3, 1995) (FSB “İstoriya sozdaniya“, 1998)

"Rusya Federasyonu Devlet Sirları Hakkında Kanun"un 2. Maddesinde devlet sırr1; "açığa çıkması ile devlet güvenliğini zarara uğratabilecek askerî, dış politika, ekonomik, istihbarat, karşı istihbarat, operasyonel-asayiş faaliyetleri" olarak tanımlanmıştır (Zakon Rossiyskoy Federatsii O Gosudarstvennoy Tayne Statya 2, 1997). Söz konusu kanun Rusya Federasyonu istihbarat kurumlarının temel görevlerini belirlediği bir özet gibidir ve kanunun ana uygulayıcısı da FSB'dir. Kurumun görev tanımlamaları bu kanun üzerinden gidilerek oluşturulmuştur. Kurum, söz konusu devlet sırlarını korumak amacı ile sadece yurt içinde değil, yurt dışında da operasyon yapma, istihbarat toplama haklarını federal yasalarca elinde tutmaktadır.

İçişleri bakanlığg gibi militer bir yapıya sahip olan FSB'de hiyerarşi, askerî rütbe sistemine benzer bir şekilde devam etmektedir. Diğer devlet daireleri ve memurlarının öncelikle yerel-özerk yöneticilerine ve silsile olarak Moskova'daki merkeze bağlı olduğu federal düzen dikkate alındığında, FSB'nin federal yapının aksine, aracı bir yönetici olmaksızın Devlet Başkanına bağlı olduğu görülür (Andreva, 2011: 322).Özerk cumhuriyetlerde dahi kurumun yönetim ve yönlendirmesi, yerel yöneticilerden bağımsız olarak, merkezden yapılmaktadır. Söz konusu sistem, yerel düzeyde adam kayırma ya da kavmiyetçilik gibi bazı sorunların önüne geçerek birtakım avantajlar sağlanmıştır. Fakat bunun yanında özerk cumhuriyetlerdeki yerel güvenlik organlarından MVD ya da Dâhilî Ordu gibi emniyet organları ile güç mücadeleleri yaşanmaktadır. Dâhili Ordunun, Rusya Federasyonu Milli Muhafız Ordusu Federal Hizmetleri adıyla dönüştürülmesi ve merkeze bağlanması, Özerk Cumhuriyet liderleri ile FSB generallerinin sürekli güç mücadelelerinin bir sonucudur. Sürekli askerî yığınak ve operasyonların yapıldığ1 Kuzey Kafkasya'da, daha önce yerel yöneticilere bağlı olan Dâhilî Ordu elemanlarının (OMON, Vostok ve Zapad Taburları) sayılarının büyük ölçüde artması ve üyelerinin yerel halklardan, yerel bir yöneticiye sadakat ile bağlı bir güç oluşturması, FSB generallerinin rahatsızlığının temelini oluşturmaktadır.

Rusya Devlet başkanı Vladimir Putin'in KGB kökenli olması, FSB yönetici ve personelinin arasında, kurumun istihbarat kurumları arasında en geniş yetkilerle donatılacağı yönünde bir düşünceye neden olmuştur. Ancak Putin'in KGB geçmişi onu, istihbarat örgütleri arasında ayrım yapmaya itmemiş, bilakis Putin kurumlar arasında denge politikası gütmeyi benimsemiştir. Kadirov ve FSB arasındaki güç mücadelesini bir iç güvenlik yetki sorununun sancıları olarak algılamak yanlış olmaz. Ancak Rusya Askerî İstihbarat Örgütü (GRU) ile girişilen 
mücadele, Kırım'ın işgali, Donbas ve Lugansk ayrılıkçılarının desteklenmesi bağlamında güç savaşına dönmüştür. ABD istihbarat ve analiz ajansı Stratfor'un raporunda, FSB ve GRU arasında var olan güç mücadelesinin Ukrayna sorunu ile şiddetlendiği ve karşıllklı algı operasyonları ile rakip kurumu hükümet önünde itibarsızlaştırmaya çalıştı̆̆ iddia edilmektedir. Yine rapora göre GRU lideri İgor Sergun'un Ocak 2016'da şüpheli ölümünün arkasında iki kurum arasındaki güç savaşının olduğu belirtilmektedir (NEWSRU, 2016).

"Rusya Federasyonu Federal Emniyet Hizmetleri Hakkında Kanunu"nun 2 numaralı ana başlığ 1 altında FSB'nin görev tanımı ve faaliyet alanları "karş1 istihbarat, terörizmle mücadele, suçla mücadele, istihbarat, sınır güvenliği ile enformasyon güvenliğinin sağlanması" olarak 6 başlık altında belirtilmiştir (Zakon ot 03.04.1995 N 40-F3 Glava 2, 1995).

FSB ve Milli İstihbarat Teşkilatı (MİT) ile bir kıyaslama yapıldığında, FSB'nin organizasyon yapısında sadece bilgi toplama olmadığı, kurumun ayrıca operasyonel bir kuvvete de sahip olduğu görülmektedir. Özellikle terörle mücadele ve suçla mücadele faaliyetleri kapsamında FSB kendi istihbarat kaynaklarına dayanarak operasyon yapma ve suçlu gördügü kişileri polis kuvvetlerinden destek almadan tutuklama yetki ve olanaklarına sahiptir. FSB'nin ülkemiz iç güvenlik yapılanmalarından farklı bir diğer yanı ise ülkemizde sınır kapılarında emniyet teşkilatı tarafından gerçekleştirilen sınır güvenliği ve kontrol işlemlerini, bu kurumun yapmasıdır. Özellikle havaalanı ve karayolları pasaport kontrol noktalarında kontroller FSB teğmenleri tarafından yapılmakta, giriş ve çıkışlar FSB sisteminde kayıt altında tutulmaktadır.

FSB, içerisinde 4 ana bölüm ve 6 alt bölüm bulundurmaktadır. Ana bölümler;

- Ana gövde olan, barındırdığı bölüm ve dairelerin gizli tutulduğu FSB Rusya bölümü

- Federasyon içerisindeki özerk cumhuriyetlere ve diğer bölgelere ait bölgesel emniyet organları bölümü

- Rusya Federasyonu Silahlı Kuvvetleri ve ona bağlı kuvvetleri de bünyesinde bulunduran silahlı kuvvetler güvenlik organı

- Rusya Federasyonu sınır güvenlik ve hizmetlerinin verildiği sınır bölümü

şeklindedir. Alt bölümler ise; havacılık, bilimsel-araştırma, eğitim kurumları ve merkezleri, bilirkişi ve mahkeme bilirkişileri, özel amaçlar ve askerî tıp ile ilgilidir (FSB "Struktura", 1998). 


\section{FEDERAL GÜVENLİK HİZMETLERİ(FSO)}

Federal Güvenlik Hizmetleri, Rusya Federasyonu devlet büyüklerinin, onların yerleşkelerinin ve geçtikleri yolların güvenliğinin sağlanması üzerine kurulu bir iç güvenlik organıdır. Daha ziyade Kremlin Sarayı girişlerinde tarihi üniformaları ile görülebilecek FSO görevlileri, diğer iç güvenlik organlarının gönderdikleri bilgiler ve istihbaratlar ile güvenlik önlemleri almaktadır. Oldukça eski bir geçmişi olan FSO'nun kökleri, IV. Çirkin İvan'ın Kremlin Sarayını korumak üzere oluşturduğu 2000 kişilik saray muhafızı birliğine dayandırılmaktadır (FSO "Ob İstorii Sozdaniya Organov Gosudarstvennoy Ohrany v Rossii“, 2016). İsmi çok göz önünde olmayan bu kurum, Rusya Federasyonu Devlet başkanını, üst düzey devlet yöneticilerini, yabancı devlet başkanlarını, ailelerini ve onların heyetlerini korumak, güvenlik önlemlerini almak şeklinde önemli birtakım görevler üstlenmektedir (Zakon ot 27 maya 1996 N 57-F3, 1996).

Devlet başkanına doğrudan bağlı olan FSO, federasyon genel seçimlerinin sonunda oy sonuçlarının kamuoyu ile paylaşılmasından itibaren başkanın güvenliğinden sorumludur ve devlet başkanı görevi boyunca güvenlik hizmetini reddetme hakkına sahip değildir (Zakon ot 27.05.1996 N 57-F3, 1996). Kurumda, diğer iç güvenlik organlarında olduğu gibi rütbeler askerî sisteme ve hiyerarşiye göre sıralanır. Kurumun başında bir general bulunmaktadır. Ülkemiz iç güvenlik kurumları arasında doğrudan bağımsız kurumsal bir muadili bulunmamakla birlikte Emniyet Genel Müdürlüğü Devlet Büyüklerini Koruma Şubesi örnek olarak verilebilir. Personellerinin eğitimlerinin bitiminden emekli olana dek koruma hizmetleri üzerine çalışmaları tecrübe açısından sürekli gelişmelerine olanak sağlamaktadır.

Kurumun personel ve yönetici ihtiyac1, Voronezh ve Orel şehirlerinde bulunan kuruma bağlı Rusya Federasyonu Federal Güvenlik Hizmetleri Akademisi tarafından sağlanmaktadır. Akademi lisans düzeyinde eğitim vermekte, mezunlarına akademik kariyer imkânı da sunmaktadır (Akademiya Federalnoy sluzhbu ohrany Rossiyskoy Federatsii, 2005).

\section{RUSYA FEDERASYONU GÜVENLİK KURULU}

Rusya Federasyonu Güvenlik Kurulu, güvenliğin temini alanında Rusya Federasyonu başkanının kararlarının hazırlanması için kurulmuş anayasal bir organdır. Kurul devlet başkanı başkanlığında sekreter, üyeler ve daimi üyelerden oluşmaktadır, sekreter daimi üyeler arasından seçilmektedir. Üye ve daimî üyelerin kurula seçilmesi ya da kuruldan çıkarılması sekreterin önerisi ve başkanın onayı ile olmaktadır (Zakon ot 5 marta 1992 N2446-I razdel III, 1992). Görev ve sorumlulukları açısından ülkemiz Milli Güvenlik Kuruluna benzer bir yapısı olmakla birlikte üye sayısı ve görevleri açısından farklı bir yapıya sahiptir. 
Genelkurmay başkanı dışında asker üyesi bulunmayan kurul, ağırlıklı olarak sivillerden oluşmaktadır. Kurul üyeleri aşağıdaki gibidir:

\subsection{Kurul Başkanı:}

- Rusya Federasyonu Devlet Başkanı

\subsection{Daimi Üyeler:}

- Federal Emniyet Hizmetleri Direktörü (FSB)

- Başkanlık İdari Başkanı

- Devlet Duma Federal Meclis Başkanı

- Devlet Başkanı Çevre Koruma Faaliyetleri, Ekoloji ve Ulaştırma Özel Temsilcisi

- İçişleri Bakanı (MVD)

- Dışişleri Bakanı

- Federal Meclis Federasyon Konseyi Başkanı

- Başbakan

- Diş İstihbarat Hizmetleri Direktörü (SBR)

- Güvenlik Kurulu Sekreteri

- Savunma Bakanı

4.3. Üyeler:

- Volga Federal Bölgesi Tam Yetkili Rusya Federasyonu Başkan Temsilcisi

- Merkez Federal Bölgesi Tam Yetkili Rusya Federasyonu Başkan Temsilcisi

- Kuzey Kafkasya Federal Bölgesi Tam Yetkili Rusya Federasyonu Başkan Temsilcisi

- Federal Gümrük Hizmetleri Yöneticisi

- Rusya Federasyonu Genelkurmay Başkanı (Savunma Bakanı 1.Yardımcısı)

- Federal Milli Muhafız Ordusu Hizmetleri Direktörü (Milli Muhafız Ordusu Başkumandanı)

- Adalet Bakanı

- Sibirya Federal Bölgesi Tam Yetkili Rusya Federasyonu Başkan Temsilcisi

- Güvenlik Kurulu Sekreter yardımcıs1

- Petersburg Valisi

- Rusya Federasyonu Sivil Savunma, Olağanüstü Hal Ve Afet Yardim Bakanı (MÇS)

- Maliye Bakanı

- Moskova Belediye Başkanı

- Uzakdoğu Federal Bölgesi Tam Yetkili Rusya Federasyonu Başkan Temsilcisi

- Güney Federal Bölgesi Tam Yetkili Rusya Federasyonu Başkan Temsilcisi

- Uralsk Federal Bölgesi Tam Yetkili Rusya Federasyonu Başkan Temsilcisi 
- Kuzeybatı Federal Bölgesi Tam Yetkili Rusya Federasyonu Başkan Temsilcisi

- Rusya Federasyonu Başsavcısı

Kurulun ana faaliyet alanları aşağıdaki gibidir (Sovet Bezopasnosti Rossiyskoy Federatsii.“ İstoriya sozdaniya, pravovoy status, struktura i osnovnye napravleniya deyatelnosti”, 2000) :

- İç, dış ve askerî politikalar, bireylerin hayati çıkarlarının korunması için yasal araçların geliştirilmesi, toplum ve devlete gelecek iç ve diş tehdit sorunlarına göre Rusya'nın güvenliğinin sağlanması adına icra organlarının temel program evrakları hakkında Rusya Federasyonu Başkanlığı yüksek konseyine yıllık dosyanın hazırlanması,

- Rusya Federasyonu devlet başkanının karar projelerinin gelişimi için temel araç olarak, işlevsel ve bölgesel bazda, güvenlik konseyi tarafından oluşturulan bakanlıklar arası kalıcı ya da geçici organizasyon işler komisyonunun oluşturulması,

- Belirlenmiş anayasanın, Rusya Federasyonu anlaşma ve kanunları sınırları içerisinde Rusya Federasyonu'nun toprak bütünlüğü, devlet egemenliği ve anayasal düzenin korunması için önerilerin geliştirilmesi.

5 Mayıs 2011 yılı 590 numaralı Rusya Federasyonu Başkanının kararnamesine göre kurulun görevleri aşağıdaki gibi sıralanmıştır (Ukaz Prezidenta RF ot 06.05.2011 N590, 2014) :

- Milli güvenliğin sağlanması alanında, başkanın yetkileri için koşulların sağlanmas1,

- Milli güvenliğin sağlanması ve gerçekleştirilmesi için devlet politikalarının oluşturulması,

- Milli güvenlik tehlikelerine dair öngörüde bulunma, tehlikeleri açı̆̆a çıkarma, analiz ve değerlendirilmesini yapma, askerî tehlike ve askerî tehditleri değerlendirme, bunların etkisiz hale getirilmesi için önlemler üretme,

- Devlet başkanına teklif hazırlanması,

- Olağan üstü halleri bertaraf ve önceden ikaz etme önlemleri ve sonuçlarının üstesinden gelme,

- Milli güvenliğin temini amacıyla özel ekonomik tedbirlerin alınması,

- Olağanüstü hallere giriş, olağanüstü halin uzatılması ya da kaldırması, savaş haline giriş ya da savaş kararının kaldırılması,

- Milli güvenliğin sağlanması alanında devam eden ya da yeni kurulacak devlet organları ve organizasyonlarının 1slahı, bunların daha işlevsel bir hale getirilmesi, 
- Milli güvenlik ve savunma alanında bazı konsept ve doktrinlerin, Rusya Federasyonu milli güvenlik stratejisi adına belirlenmesi ya da onaylanması,

- Devlet dış ve askerî politikalarının ana istikametinin biçimlendirilmesi.

- Milli güvenliğin sağlanması alanında federal icra organlarının faaliyet koordinasyonu ve icra makamı olan organların, başkanın emrini uygulanmasının hayata geçirilmesi,

- Milli güvenliğin sağlanması alanında federal icra makamlarının göstergelerinin, etkinlik değerlendirmesi, kriterlerin belirlenmesi.

Güvenlik kurulunun yukarıdaki görevleri incelendiğinde 'Milli güvenliğin temini amacıyla özel ekonomik tedbirlerin alınması' maddesi ülkemizin 2015 ve 2016 yıllarında gündeminden düşmemiş hatta iki ülkeyi savaşın eşiğine getiren önemli maddelerden biri haline gelmiştir. Ülkemiz hava sahasını ihlal ettiği gerekçesi ile 24 Kasım 2015'de düşürülen Rus Su-24 savaş uçağının düşmesinin akabinde, Rusya Federasyonu Güvenlik Kurulu acil olarak toplanmış ve söz konusu görev tanımı itibarıyla gerekli yaptırım için teklif ve öneriler kurulda sunulmuştur. (Ntv Haber, 2015). 28 Kasım 2015'te, “Canice ve bazı haksız faaliyetlerden dolayı Rusya'nın milli güvenliğinin temini ve Rusya vatandaşlarının korunmasına yönelik önlemler ve Türkiye ile ilişkilerde özel ekonomik önlemlerin alınması hakkında" (Rusya Başkanlık Resmî A ̆ Kaynakları, 2015) adlı 583 numaralı kararname, Rusya Devlet Başkanı Vladimir Putin tarafından onaylanmış, Türkiye'ye ekonomik yaptırımda bulunulması ve iki ülke arasındaki ekonomik ilişkilerin askıya alınması kararlaştırılmıştır (Ukaz Prezidenta Rossiyskoy Federatsii ot 28.11.2015 №583, 2015).

\section{DEVLET ALT MECLİSİ GÜVENLIKK VE RÜŞVETLE MÜCADELE KOMITESI}

Devlet Alt Meclisi Güvenlik ve Rüşvetle Mücadele Komitesi,17 Ocak 2017 tarihli, 15/8 sayılı protokoldeki görev tanımına göre, güvenlik alanında yapılacak yasama oylaması öncesi gerekli kanun tasarılarının hazırlık ve incelenmesi faaliyetini yürütmek amacı ile milletvekillerinden kurulmuş daimi bir komitedir. Rusya Federasyonu içerisinde iç ve diş güvenlik ayırt edilmemekle birlikte, tüm iç güvenlik, devlet organları ile ilgili yasa ya da kanun tasarıları ve incelenmesi söz konusu komite tarafından gerçekleştirilir (Protokol №15/8 ot 17 yanvarya 2017, 2017) (Komitet Gosudarsvennoy Dumy Po Bezopasnosti i Protivodeystviyu Korruptsii "Polozhenie i voprosy vedeniya“, 2017),

Partilerin oy sayısına göre üye sayılarının belirlendiği komitede iktidar ve muhalefet partilerinden milletvekilleri bulunmaktadır. İktidar partisi olan Birleşik Rusya Partisi'nden 15 milletvekili, muhalefet partisi Liberal Demokrat Parti'den 2 milletvekili, Komünist Parti ve Adil Rusya Partisinden 1'er milletvekilinden oluşur 
(Komitet Gosudarsvennoy Dumy Po Bezopasnosti i Protivodeystviyu Korruptsii "Sostav komiteta“, 2010).

\section{FEDERASYON KURULU EMNIYET VE SAVUNMA KOMITESİ}

Rusya Federasyonu içerisinde bulunan özerk cumhuriyetler ve diğer tüm bölgeler Moskova'da birer temsilci bulundurmaktadır. Söz konusu temsilciler, federasyon içerisindeki anayasal düzenlemelerden bilimsel çalışmaların denetlenmesine kadar tüm federal sorunların görüşüldüğü, yasaların incelendiği Rusya Federasyonu Federal Meclisi Federasyon Konseyini oluşturmaktadır. Federasyon Kurulu Emniyet ve Savunma Komitesi de diğer 22 alt kuruldan biridir (Postanovlenie Ot 30 Yanvarya 2002 N33-Sf, 2002).

Kurul 1 başkan, 3 1.derece yardımcı, 2 yardımcı ve 11 üyeden oluşmaktadır. Kurulun kuruluş ve çalışma amacı, ülke güvenliği adına federal düzeyde kanun ya da kararnamelerin ön incelemesini yapmaktır. Kurulun inceleme yaptı̆̆ 1 evrak türleri aşağıda sıralanmıştır (Komitet Soveta Fedaratsii Po Oborone i Bezopasnosti "Voprosy vedeniya", 2014) :

- Savaş durumuna geçiş hakkında devlet başkanının kararnamesi

- Olağanüstü hâl durumuna geçiş hakkında devlet başkanının kararnamesi

- Rusya Federasyonu topraklarında Rusya Federasyonu Silahlı Kuvvetlerinin kullanması imkânı hakkındaki kararlar

- Rusya Federasyonu iç ve dış güvenlik sorunlarıyla ilgili kararlar

- Askerî inşaatlar hakkındaki kararlar

- Devlet askerî kurum ve kuruluşlarına, ülke savunması ve ülke güvenliği finansmanına dair kararlar

- Uluslararası askerî ve askerî-teknik işbirliğine dair kararlar

- Kolektif Güvenlik Anlaşması Örgütü Teşkilatı ile işbirliğinin sağlanmasına yönelik kararlar

- Ordu mensuplarının, kolluk kuvvetleri ve diğer özel hizmet çalışanlarının, savunma-sanayi kompleksleri işçilerinin, gümrük organı çalı̧̧anlarının ve tüm bu çalışanların ailelerinin statülerine dair kararlar

- Ordu mensuplarının sosyal imkânlarıyla ilgili kararlar

- Askerî-vatansever ve askerî-gönüllü işleriyle ilgili kararlar

- Rusya Federasyonu devlet sınırlarındaki, hava sahalarındaki, karasularındaki ulusal çıkarlarının korunmasına, kıta sahanlığının, münhasır ekonomik bölgelerinin ve uluslararası okyanusların korunması ve statü konularına dair kararlar

- Suç, terör, yasadışı silah kaçakçılığı ve narkotik örgütler ile mücadele konularına dair kararlar

- Trafik ve ulaşım güvenliğiyle ilgili kararlar 
- Yangın güvenliğiyle ilgili kararlar

- Sivil ve yerel savunma konuları, olağanüstü hal uyarıları ve bunların sonuçlarının ortadan kaldırılmasına dair kararlar

- Askerî hizmet, kolluk kuvvetlerinin hizmetleri ve gümrük organlarının hizmetlerine dair kararlar.

\section{MILLI ANTİ-TERÖR KOMITESI (NAK)}

15 Şubat 2006 yılında Rusya Federasyonu Başkanının emriyle kurulan Milli Antiterör Komitesi (NAK), yurtiçi ve yurtdışı terör tehditlerinin önlenmesi, antiterör faaliyetlerinin organize ve koordine edilmesi, yurtiçi ve yurtdışı terörle mücadele kapsamında istihbarat raporlarının değerlendirilmesi amacı ile kurulmuş bir komitedir. Kurul, üyeleri, yapısı ve kuruluş amacı itibarıyla Rusya Federasyonu terörle mücadele faaliyetlerinde çok önemli bir yere sahiptir. Zira kurulun başkanlığını FSB direktörü yürütmektedir. İçişleri bakanı, FSB direktör yardımcısı, Rusya Federasyonu Hükümeti adına bir temsilci, Rusya Federasyonu Başkanlık İdaresi Başkanı, Rusya Federasyonu Federal Meclisi Federasyon Konseyi temsilcisi, Rusya Federasyonu Federal Meclisi Devlet Duma's1 temsilcisi, Rusya Federasyonu Sivil Savunma, Olağanüstü Hal ve Afet Yardım bakanı, dışişleri bakanı ve savunma bakanı komitenin üyelerini oluşturmaktadır. Üyelerin görevleri dikkate alındığında komite, terörle mücadele konusunda aktif rol alan bir üst organizasyon niteliğindedir. Komitenin inceleme ve değerlendirmeleri üzerine operasyon ve mücadele imkânlarının kullanılması adına karar verildiğinde, yine üyesi olan kolluk kuvveti liderlerinin imkân ve olanaklarına göre operasyon faaliyetleri daha hızlı ve başarı oranı daha yüksek sonuçlar vermektedir. Dışişleri bakanı ve savunma bakanının üyesi olduğu dikkate alındığında, komite hedef ve devlet çıkarları doğrultusunda yurtdışı terörle mücadele faaliyetleri yine bu komitede kararlaştırılmaktadır. Beşar Esad yönetimi ile Suriye topraklarında yapılan terörle mücadele operasyonları, askerî ve sosyal istihbarat raporları, çalışmaları komite değerlendirme ve yönlendirmelerine tabi tutulmaktadır (Natsianalnoy Antiterroricheskiy Komitet "Tseli i Zadachi, 2013) (Ria Novosti, 2016)."

Terörizm, ülkemiz ve diğer tüm büyük devletler için, ulusal güvenlik açısından bir iç sorun olmaktan çıkmış; uluslararası düzeyde faaliyet gösteren, saldırılarının çoğunlukla yabancı uyruklu teröristler tarafından gerçekleştirildiği bir yapıya evrilmiştir. Terörle mücadelede, orduların ya da kolluk kuvvetlerinin tek başına çalışmalarının yeterli olmadığı ve tüm devlet dairelerinin ortaklaşa mücadele etmesi gerektiği ortaya çıkmıştır. Ayrıca günümüz terör örgütlerinin siber güce sahip olduğu ve diğer elektronik imkânları usta bir istihbarat örgütü seviyesinde kullandığ 1 düşünüldüğünde, alınan en ufak bir bilginin bile önem düzeyi dakikalar ile ölçülmektedir. $\mathrm{Bu}$ sebeple, günümüz şartlarında terörle 
mücadele kapsamında her bilginin hızlı ve doğru bir yöntemle analiz edilmesi gerekliliği hissedilerek 2010 y1lında ülkemizde Türkiye Cumhuriyeti İçişleri Bakanlığına bağlı olarak kurulan Kamu Düzeni ve Güvenliği Müsteşarlığ1 (KDGM) kurulmuştur. Müsteşarlığın amacı, "terörle mücadeleye ilişkin politika ve stratejileri geliştirmek ve bu konuda ilgili kurum ve kuruluşlar arasinda koordinasyonu sağlamak" olarak ifade edilmiştir (T.C. İçişleri Bakanlığı Kamu Düzeni Ve Güvenliği Müsteşarlığ1 "Tarihçe", 2011). Ancak müsteşarlık, kuruluş amacın1, kuruluşundan günümüze kadar istenilen ve planlanan misyonunu gerçekleştirememiştir. KDGM, hedef ve misyon olarak NAK ile aynıdır. Misyon ve hedeflerinin hayata geçirilebilmesi adına, yönetimsel ve yapısal olarak NAK, işleyen bir örnek niteliğindedir. NAK'ın komite üyelerinin aynı zamanda kolluk kuvvetlerinin lider ve yöneticileri olması durumunun, ülkemizin en büyük sorunlarından biri olan istihbarat paylaşım sorununu ortadan kaldırabilecek bir model olarak dikkate alınması gerekmektedir.

\section{RUSYA FEDERASYONU ULUSAL MUHAFIZ HIZMETLERI (ROSGVARDIYA)}

Dâhilî Ordu'nun bölgesel yapılardan etkilenmesi ve geçmiş büyük terör operasyonlarındaki başarısızlıkları, yenilenmeyi ihtiyaç haline getirmiştir. Rusya Federasyonu Anayasasının 80. Maddesine ${ }^{5}$ atfen, 5 Nisan 2016 tarih ve 157 say1l kararname ile daha önce içişleri bakanlığının bir ana kolu olan Dâhilî Ordu, Rusya Federasyonu Ulusal Muhafizları Hizmetleri'ne (ROSGVARDIYA) dönüştürülmüştür. Söz konusu kurum yapı itibarıyla FSB ile benzerdir, doğrudan devlet başkanına bağlanmıştır. 2000-2013 yılları arasında Vladimir Putin'in koruma müdürlügünü yapan Zolotov Viktor Vasilevich, kurumun fikir babas1 olarak anılmaktadır. Zolotov, ROSGVARDIYYA'nın kurulmasının akabinde kurum direktörü ve başkomutanı sıfatı ile kurumun başına getirilmiştir (Rosgvardiya "Rukovodstvo", 2016). Özel kuvvetler kökeninden gelen Zolotov bordo bere ${ }^{6}$ sahibidir. Zolotov, Vladimir Putin'in en yakın adamlarından biri olması, kurumun her zaman hükümet tarafindan desteklenmesini ve en gözde kurum olmasını sağlamaktadır.

\footnotetext{
5 80.Madde: Rusya Federasyonu Başkanı Rusya Federasyonu anayasası, kişi ve vatandaşların hak ve özgürlüklerinin garantörüdür. Rusya Federasyonu Anayasası temel alınarak, Rusya Federasyonu egemenliğinin korunması, devletin bağımsızlığı, bütünlüğü, icra organlarının koordineli çalışması ve aralarında etkileşim sağlamak adına önlemler alır. http://www.constitution.ru/10003000/100030006.htm, (Erişim Tarihi:23.03.2017)

${ }^{6}$ Özel kuvvetler birlikleri içerisinden gönüllü olan askerlerin zor sınav ve testler sonrası almaya hak kazandıkları beredir. Bordo bere sahibi özel kuvvetler personelleri Rusya Silahlı kuvvetleri ve kolluk kuvvetleri içerisinde elit bir yere sahiptir.
} 
ROSGVARDIYYA'nın kuruluşunda, anayasanın 80. Maddesine atıf yapılması, devlet egemenliği, bağımsızlığı, bütünlügü, kurumlar arası koordinasyon vb. konularda bir şeylerin ters gittiği ve düzeltilmesinin toprak bütünlüğü ve egemenliği adına bir adım olduğu yönünde görüş bildirmek, çok da yanlış olmaz. Makalenin FSB bölümünde bahsedildiği gibi ROSGVARDIYYA'nın kuruluşunda, FSB generallerinin rahatsızlıklarının büyük payı vardır. Sayıları 20 bini bulan, Kadirov'a bağlı Çeçen ve İnguşlardan oluşan özel kuvvetler personeli sadece Çeçenistan'da görev yapmaktadır. Sayının büyük miktarda oluşu ve personelin eğitimli olmas1, FSB generalleri ve Kadirov'un güç mücadelesinin ana sebebini oluşturmaktadır. Andrey Piontkovskiy gibi Rus siyaset bilimciler, bu hamlenin ve akabinde Kadirov'un görevden alınması gibi bir gelişme olması halinde III. ÇeçenRus Savaşına sebebiyet vereceği öngörüsünde bulunmaktadır (Kurilenko A., 2016).

Stavropol MVD kuvvetleri, ROSGVARDIYA'nın kuruluşundan 1 yıl önce, 19 Nisan 2015'te, Çeçenistan'da bir silahlı çatışmaya dahil olmuştur. Başkent Grozni'de büyük bir futbol maçı sırasında, stadyum yanında yaşanan silahlı çatışma sonrası, Canbulat Dadaev adındaki şahıs yakalanmıştır ${ }^{7}$. Yapılan operasyon, Çeçen özerk yönetimi tarafından bir hakaret olarak algılanmış ve 23 Nisan 2015'te Kadirov, şahsi Instagram hesabından daha önce kendisine bağlı olan generallere atfen "Resmî emrimdir, bölgenizden bilginiz olmadan Moskova ya da Stavrapollü kuvvet görürseniz, öldürme amaçlı ateş açın" şeklinde, ciddi sonuçlar doğurabilecek bir emir yazısı paylaşmıştır (Raybman, 2015). Bu olaylar zinciri ROSGVARDIYYA'nın kuruluş sebeplerinin ana nedenlerindendir ve iç güvenlik adına ciddi sonuçlar doğurabilecek bu tarz eylemlerin önüne geçmek ve merkezi yönetimi güçlendirmek amacı ile kurulmuştur. Ülke yönetiminde federal düzenin bazı iç güvenlik sorunlarını beraberinde getirdiği düşüncesinin sonucu ortaya çıkan kurumun, federal yapının iç güvenliği sağlamak adına By-Pass edilmesi amacı ile kurulduğu düşünüldügünde Ülkemiz iç güvenlik kurumları arasından bir muadili söz konusu değildir.

Kuruluş amacı itibarıyla iç güvenlik özel birliklerini tek bünyede merkeze bağlı bir halde toplamak olan ROSGVARDIYYA, daha önce MVD' ye bağlı özel birlikleri bünyesinde toplamıştır. Kurumun, idari personeli ve bina güvenlikleri hariç olmak üzere Moskova merkez binası bünyesinde maksimum 2100 personeli bulundurmaktadır (Ukaz Prezidenta RF ot 20 sentyabrya 2016 N482, 2016). İnterfaks Haber Ajansının haberine göre eski Dâhilî Ordu generali Anatoliy Kulikov, personel sayısının ROSGVARDIYA'ya devri sırasında 170 bin olduğunu

7 İlgili haber için bk.: https://www.novayagazeta.ru/articles/2015/04/25/63982-kak-stavropolskayapolitsiya-vozvraschala-chechnyu-v-rossiyu, (Erişim Tarihi:24.03.2017) 
ve yeni birimlerin kurulması ile sayısının 300 bine çıkacağının tahmin edildiğini belirtmiştir (İnterfaks Haber Ajansı, 2016). Personel sayısı ve kullandığı araçlar itibarıyla birçok ülkenin toplam asker sayısının üzerinde olan bu iç güvenlik kuruluşu, böylesine geniş bir coğrafyada iç güvenlik faaliyetlerinin ne kadar zor ve maliyetli olduğunun bir kanıtı niteliğindedir.

ROSGVARDIYA'nın bünyesinde çeşitli özel birlikler bulunur. Bunlar COBR ve OMON olarak iki ana birlik altında toplanmış olup çatı niteliğinde bir yapıdadırlar. COBR ve OMON'u birbirinden ayıran en önemli özellik, COBR' un sadece subayların alındığı bir birim olmasıdır. Özel personel ise ZUBR, RIYS ve YASTREB adları altında 3 alt özel birime ayrılmakta, niteliklerine göre görev almaktadırlar (Rosgvardiya "Obshie dannye", 2016). Rusçada "bizon" anlamına gelen ZUBR, Mobil Özel Birimi’nin kısa adıdır. Genel özel harekât birimi olup, özel operasyon gerektiren faaliyetlere katılmaktadırlar. Rusçada "vaşak" anlamına gelen RIYS, Özel Acil Müdahale Birimlerinin kısa adıdır. Terör olayları ve diğer toplumsal olaylar ile asayiş olaylarında stratejik ve taktik operasyonlar gerçekleştiren birim, acil müdahale gerektiren operasyonlara katılmaktadır. Rusçada "atmaca" anlamına gelen YASTREB, Özel Acil Müdahale, Havacılık Gücü ve Havacılık Birimleri'nin kısa adıdır. Genellikle helikopter ile olay yerine müdahale eden birim, bina ve tesislere havadan indirme ya da çatışma sahasının gerisine indirme gerekliliğinde devreye girmektedir. Diğer özel kuvvetler ya da iç güvenlik birimlerinin çatışmalarında insansız hava araçları ile istihbarat konusunda da destek vermektedir.

ROSGVARDIYA'nın personel sayısı ve kullandığı araç adetleri, tarafımızca tablolaştırılarak aşağıda verilmiştir (Kommersant, 2016) :

Tablo-1. Personel Sayıs1

\begin{tabular}{|l|c|c|c|c|c|}
\hline & OMON & SOBR & ZUBR & RIYS & YASTREB \\
\hline $\begin{array}{l}\text { Personel } \\
\text { Sayısı }\end{array}$ & 40000 & 5200 & 421 & 200 & 100 \\
\hline
\end{tabular}

Tablo-2. Kullanılan Araç Adedi

\begin{tabular}{|c|c|c|c|c|c|c|}
\hline & Tank & $\begin{array}{c}\text { Zırhlı } \\
\text { Taşıyıcı }\end{array}$ & Top Tertibatı & Uçak & Helikopter & Araç \\
\hline Adet & 9 & 1650 & 35 & 29 & 70 & - \\
\hline
\end{tabular}


Yukarıda bahsi geçen ROSGVARDIYA birimleri özel amaçlı operasyonlar için kurulmuştur ve kuruluş amacı olarak ülkemiz Özel Hareket Başkanlığına benzer bir yapı oluşturmaktadırlar. Kurumun görevleri arasında; terör ve aşırıcılık ile mücadele, diğer MVD organlarıyla birlikte kamu düzeni, kamu güvenliği ve olağanüstü halleri ilgilendiren konulara katılım, Rusya Federasyonu toprak savunmasıyla ilgili operasyonlara katılım, FSB ile birlikte sınır güvenliklerinin sağlanması, stratejik notların emniyeti, boru hatları ve enerji hatlarının emniyeti, devlet koruması altında olan kişilerin güvenliğine dair görevler ve devlet başkanının vereceği diğer görevler bulunmaktadır (Zakon ot 3 iyulya 2016 N226F3 Statya 2, 2016).

\section{FEDERAL ÖZEL İNŞAATLAR AJANSI}

31 Mart 1951 tarihinde Sovyet Sosyalist Cumhuriyetler Birliği İçişleri Bakanlığı'na (MVD SSCB) bağlı olarak özel askerî, nükleer, kimyasal ve diğer bilimsel tesislerin kurulması, fabrika, bina, yerleşke, tesis ve yolların inşasını üstlenmesi amacı ile kurulmuştur. Görev alanının içerisine uzayla ilgili proje binaları da giren kurum, bu projeler kapsamında Apollo uydu ve uzay üssü programlarının tesislerini de inşa etmiştir. Günümüz şekline, 16 Ağustos 2004 tarihli 1084 sayılı devlet başkanı kararnamesi ile ulaşan Federal Özel İnşaatlar Ajansı, dünyaca bilinen birçok bina ve tesisin yapılmasına imza atmıştır (Ukaz Prezidenta Rossiyskoy Federatsii ot 16.08.2004 №1084, 2004).

Rusya Federasyonu iç güvenlik anlayış ve uygulamalarına bağlı olarak, Sovyet sisteminin bir parçası olan şehir ve kasabaların tüm giriş ve çıkışlarına inşa edilen "post”lar, 2009 yılına kadar varlığını sürdürmüştür. Dönemin Devlet Başkanı Dimitry Medvedev'in liberal bir kararı ile sayılarında ciddi bir azaltmaya gidilmiştir ${ }^{8}$. Postlar betonarme binalar halinde kurulup, Post DPS ( karayolu kontrol hizmetleri noktasi) olarak anılan birimler tarafindan araç ve yolcu kontrollerinin sıkı bir şekilde yapıldığı noktalardır. Söz konusu noktalar Federal Özel İnşaatlar Ajanslar Tarafından inşa edilip, yine bakım ve onarım işleri ajans tarafindan yapılmaktadır (Bbc Haber Ajans1, 2010).

\footnotetext{
8 Söz konusu Liberal karar Kuzey Kafkasya Federal Bölgesi için geçerli olmamıştır. Rusya Federasyonu'nun nerdeyse tüm bölgelerinde sayıları ciddi bir oranda azaltılan kontrol noktaları olan "post”lar, Kuzey Kafkasya federal bölgesinde azalmak bir yana, yeni noktaların inşası ile devam etmektedir. Prensip olarak kaçakçılık, adli suçlarla mücadele, terörle mücadele, vb. faaliyetler açısından faydalı olabileceği düşünülse de yapılan keyfi ve gayriciddi uygulamalar ile insanlar saatlerce noktalarda bekletilmekte ya da memurlar tarafindan uydurma bahaneler ile rüşvet talep edilmektedir.
} 


\section{SONUÇ}

Rusya Federasyonu iç güvenlik organlarının birçoğu, Soğuk Savaş sonrasında, Putin yönetimi tarafından günümüz şartlarına uygun hale getirilmiştir ya da getirilmeye devam edilmektedir. ROSGVARDIYYA örneğinde olduğu gibi, devletin federal yapısı ve yerel özerk yönetimlerinin kanunları, büyük ve zor bir coğrafyada iç güvenliğin sağlanması hususunda kendine has çözümler bulma zorunluluğu getirmiştir. Milli Anti-terör Komitesi (NAK) gibi üst kurullar ise sürekli terör saldırılarının gündeme geldiği ülkede, terör saldırılarına karşı acil eylem planı oluşturulmasında ve müdahalede ciddi yararlar sağlamaktadır. Nerdeyse tüm iç güvenlik organlarının eleman ve personel teminlerinin akademik olarak kendi bünyelerinde bulunan üniversite ve enstitüler vasıtası ile yetiştirmesi, donanımlı ve işinin ehli bir yapının oluşmasında en büyük faktördür. Tarihsel olarak ülkemiz ile birçok ortak noktası bulunan Rusya, Sovyetler sonrası iç güvenlik organlarındaki büyük yapılanması ve daha fazlası ile ülkemiz iç güvenlik organlarına örnek oluşturabilecek niteliktedir.

Yerel halk ve yapılar açısından, iç güvenlik faaliyetlerinde devlet organlarının azami dikkat göstermeleri gerekliliği ortaya çıkmaktadır. Özellikle Kuzey Kafkasya bölgesindeki özerk cumhuriyetlerde birtakım keyfi uygulamalar bazen önünün alınamadığı toplumsal olaylara dönüşebilmektedir. Rus Kazakları örneğinde olduğu gibi iç güvenlik politikalarında yapılan bazı yanlış ya da kısmen taraflı uygulamalar, özerk cumhuriyetler açısından domino etkisi yaratabilecek potansiyele sahiptir.

Rusya Federasyonu'nun iç güvenlik yapıları, diğer sosyal ve siyasal yapıları sosyal istihbarat doğrultusunda incelenmesi büyük bir önem arz etmektedir. FSB ve Kadirov arasında oluşan güç mücadelesi sosyal istihbarat temelinde incelenmediğinde mümkün gözükmemekte, ancak gelişen olaylar yerel hassasiyetler bağlamında birçok çatışmayı mümkün kılabilmektedir.

Askerî gücünün büyük bir bölümü, uluslararası camia ve ülkemiz açısından büyük bir sorun teşkil eden Suriye'de bulunan, deniz kuvvetlerinin önemli bir kısmı Karadeniz'de konuşlu Rusya Federasyonu, sahip olduğu nükleer güç açısından dünyada ikinci sıradadır. Bu sınır komşumuzun, ülkemiz güvenliği ve uluslararası politikalar açısından daha derinlemesine incelenmesi ve analizlere tabi tutulmasi gerekmektedir. 


\section{KAYNAKÇA}

Akademiya Federalnoy sluzhbu ohrany Rossiyskoy Federatsii, (2005), http://academ.msk.rsnet.ru/index.html, (Erişim Tarihi:21.03.2017).

Andreva O.İ vd, (2011). Pravoohranitelnye Organy. Tomsk: İzdatelstvo NauchnoTeknicheskoy Literaturi.

BBC HABER AJANSI, (2010). "Chem zamenit dorozhnye posty GIBDD?", http://www.bbc.com/russian/russia/2010/04/100401_gibdd_checkpoints_clo sure.shtml, (Erişim Tarihi:23.03.2017).

Bykovskiy V.İ, (2002)."Kazaki v sisteme MVD”, Jurnal Pravo i Bezopasnost, Say1: 2, 2-4.

FSB "İstoriya sozdaniya“, (1998). http://www.fsb.ru/fsb/history.htm, (Erişim Tarihi:20.03.2017).

FSB "Struktura", (1998). http://www.fsb.ru/fsb/structure.htm, (Erişim Tarihi:21.03.2017).

FSO “Ob İstorii Sozdaniya Organov Gosudarstvennoy Ohrany v Rossii“, (1998). http://www.fso.gov.ru/histori/p1.html, (Erişim Tarihi:21.03.2017).

İnterfaks Haber Ajansı, (2016). "Veroyatnuyu chislennost Natsgvardii v Rossii otsenili v 300 tys. Chelovek", http://www.interfax.ru/ russia/502568, (Erişim Tarihi:26.03.2017).

İstoriya MVD Rossii, (2000). https://xn--b1aew.xn--p1ai/history/1966_2010, (Erişim Tarihi:18.03.2017).

Komitet Gosudarsvennoy Dumy Po Bezopasnosti i Protivodeystviyu Korruptsii "Polozhenie i voprosy vedeniya“, (2017). http://www.komitet216.km.duma.gov.ru/Polozhenie-i-voprosy-vedeniya,

(Erişim Tarihi:23.03.2017).

Komitet Gosudarsvennoy Dumy Po Bezopasnosti i Protivodeystviyu Korruptsii. "Sostav komiteta“, (2010), http://www.komitet2-16.km.duma.gov.ru/SostavKomiteta, (Erişim Tarihi:23.03.2017).

Komitet Soveta Fedaratsii Po Oborone i Bezopasnosti "Voprosy vedeniya",(2014). http://defence.council.gov.ru/structure/maintenance_issues/, (Erişim Tarihi:23.03.2017).

Kommersant, (2016). "Chto nuzhno znat pro natsionalnuyu gvardiyu", http://kommersant.ru/doc/2956897, (Erişim Tarihi:26.03.2017). 
Kurilenko, A, (2016). "Putin vydvinul ultimatum Ukranie, a v Kremle idet "shvatka buldogov", $\quad$ https://m.online.ua/news/745311/, (Erişim Tarihi:24.03.2017).

Milletler Federal Ajans1, (2015). "Polozhenie o Federalnom agentstve po delam natsionalnostey", http://fadn.gov.ru/agency/polozhenie-ob-agentstve, (Erişim tarihi:23.03.2017).

MVD "Priem na sluzhbu, (2000). https://xn--b1aew.xn--p1ai/Deljatelnost /work/recruitment, (Erişim Tarihi:18.03.2017).

MVD "Struktura Ministerstva", (2000). https://xn--b1aew.xn--p1ai/mvd/structure1, (Erişim Tarihi:18.03.2017).

MVD Obrazovatelnaya sistema", (2000). https://xn--b1aew.xn--p1ai/Deljatelnost/ work/education, (Erişim Tarihi:18.03.2017).

Natsianalnoy Antiterroricheskiy Komitet "Tseli i Zadachi, (2013). http://nac.gov.ru/nak/celi-i-zadachi.html, (Erişim Tarihi:24.03.2017).

NEWSRU, (2016). "Amerikanskie razvedchiki rasskazali o borbe GRU i FSB za vliyanie i ukrainskom unizhenie rossiyskih spetssluzhb", http://www.newsru.com/world/07jan2016/serg.html\#, Tarihi:24.03.2017).

NTV Haber, (2015). "Rus savaş uçağı sınırı ihlal etti, Türk F-16'lar düşürdü”, http://www.ntv.com.tr/turkiye/rus-savas-ucagi-siniri-ihlal-etti-turk-f-16lardusurdu,_mP74HrTmEe3cc8qXBIqrA, (Erişim Tarihi:21.03.2017).

Postanovlenie Ot 30 Yanvarya 2002 N33-Sf, (2002). http://pravo.gov.ru/ proxy/ips/?docbody $=\& n d=102074679 \& \mathrm{rdk}=\&$ backlink=1, (Erişim tarihi: 23.03.2017).

Protokol №15/8 ot 17 yanvarya 2017, (2017). http://www.komitet216.km.duma.gov.ru/Polozhenie-i-voprosy-vedeniya, (Erişim tarihi: 23.03.2017).

RAYBMAN, Nataliy (2015). "V Kremle izuchat zayavleniya Kadirova o nesoglasovannyh operatsiyah silovikov iz chuzhih regionov", http://www.vedomosti.ru/politics/articles/2015/04/23/v-kremle-izuchatzayavleniya-kadirova-o-nesoglasovannih-operatsiyah-silovikov-iz-chuzhihregionov (Erişim Tarihi:24.03.2017).

RİA Novosti, (2011) "Proishozhdenie nazvaniy "politsya" i "militsya". Spravka", https://ria.ru/spravka/20110301/340146365.html, (Erişim Tarihi: 18.03.2017). 
RİA Novosti, (2016). "NAK: pik vyezda rossiyan v Siriyu dlya uchastiya v İG proyden", https://ria.ru/incidents/20160129/ 1366967341.html, (Erişim Tarihi:24.03.2017).

Rosgvardiya "Obshie dannye", (2016). http://rosgvard.ru/o-vojskah/obshhiedannye/, (Erişim Tarihi:26.03.2017).

Rosgvardiya "Rukovodstvo", (2016). http://rosgvard.ru/o-vojskah/rukovodstvo/, (Erişim Tarihi:24.03.2017).

Rusya Başkanlık Resmi Ağ Kaynakları, (2015). ”Ukaz o merah po obespecheniyu natsionalnoy bezopasnosti Rossii i zashite grazhdan Rossii ot prestupnyh i inyh protivopravnyh deystviy i o primenenii spetsialnyh ekonomicheskih mer v otnoshenii Turtsii", http://kremlin.ru/events/president/news/50805, (Erişim Tarihi: 21.03.2017).

Rusya Federasyonu Anayasas1 3.bölüm-Federal Yap1. 65.madde, (1995). http://constitution.kremlin.ru/, (Erişim Tarihi: 19.03.2017).

Sovet Bezopasnosti Rossiyskoy Federatsii.“ İstoriya sozdaniya, pravovoy status, struktura i osnovnye napravleniya deyatelnosti”, (2000). http://www.scrf.gov.ru/about/history/, (Erişim Tarihi:21.03.2017).

T.C İçişleri Bakanlığı Kamu Düzeni Ve Güvenliği Müsteşarlığı, Tarihçe, (2011). http://www.kdgm.gov.tr/?ax=kdgmHakkimizda, (Erişim Tarihi:24.03.2017).

Tavkul, Ufuk, (2005). Kafkasya'nın Hassas Etnik Dengelerinde Yeni Bir Tehdit Unsuru "Kazaklar". Değişen Dünya Düzeninde Kafkasya. İstanbul: Kitabevi.

Ukaz Prezidenta RF ot 06.05.2011 N590, (2014). http://www.consultant.ru/ document/cons_doc_LAW_113807/,(Erişim Tarihi: 21.03.2017).

Ukaz Prezidenta RF ot 20 sentyabrya 2016 N482, (2016). http://www.kremlin.ru/acts/bank/41260, (Erişim Tarihi:26.03.2017).

Ukaz Prezidenta Rossiyskoy Federatsii № 157 ot 5 aprelya 2016, (2016). http://kremlin.ru/events/president/news/51648, (Erişim Tarihi: 19.03.2017).

Ukaz Prezidenta Rossiyskoy Federatsii ot 09.08.1995 N835, (2013). http://www.consultant.ru/document/cons_doc_LAW_10330/4d34b7cd2c64f 4fec131f53c6e83f94ae1113226/, (Erişim Tarihi: 21.03.2017).

Ukaz Prezidenta Rossiyskoy Federatsii ot 16.08.2004 №1084, (2004). http://kremlin.ru/acts/bank/21313, (Erişim Tarihi:26.03.2017). 
Ukaz Prezidenta Rossiyskoy Federatsii ot 28.11.2015 №583, (2015). http://kremlin.ru/acts/bank/40248, (Erişim Tarihi:21.03.2017).

Zakon ot 27.05.1996 N 57-F3, (1996). http://www.consultant.ru/document/ cons_doc_LAW_10511/e75e619c65c1ce9cf81ceb4c76865bf106b4d4f3/, (Erişim Tarihi:21.03.2017).

Zakon ot 03.04.1995 N 40-F3 Glava 2, (1995). http://www.fsb.ru/fsb/ npd/more.htm\%21id\%3D10340801\%40fsbNpa.html, (Erişim Tarihi: 21.03.2017).

Zakon ot 03.04.1995 N40-F3, (1995). http://kremlin.ru/acts/bank/ 7696, (Erişim Tarihi:20.03.2017).

Zakon ot 06.10.1999 N184-F3, (2016). http://www.consultant.ru/document/ cons_doc_LAW_14058/\#utm_campaign=rss_curprof\&utm_source=rss_read er\&utm_medium=rss, (Erişim Tarihi: 19.03.2017).

Zakon ot 07.02.2011 N3-F3, (2011). http://www.consultant.ru/document/ cons_doc_LAW_110165/, (Erişim Tarihi: 19.03.2017).

Zakon ot 07.02.2011 № 3-F3, (2011). http://www.consultant.ru/document/ cons_doc_LAW_110165/, (Erişim Tarihi: 19.03.2017).

Zakon ot 18.04.1991 N1026-1, (2010). http://www.consultant.ru/document/ cons_doc_LAW_59/,(19.03.2017).

Zakon ot 25.12.2008 N273-F3, (2008), http://kremlin.ru/acts/bank/ 28623, (Erişim Tarihi: 19.03.2017).

Zakon ot 27 maya 1996 N57-F3, (1996). http://pravo.gov.ru/proxy/ips $/$ ?docbody $=\&$ nd $=102041552 \& \mathrm{rdk}=\&$ backlink $=1,($ Erişim

Tarihi: 21.03.2017).

Zakon ot 3 iyulya 2016 N226-F3 Statya 2, (2016). http://kremlin.ru/ acts/bank/40960, (Erişim Tarihi:26.03.2017).

Zakon ot 5 marta 1992 N2446-I razdel III, (1992), http://svr.gov.ru/ svr_today/doc04.htm, (Erişim Tarihi:21.03.2017).

Zakon Rossiyskoy Federatsii O Gosudarstvennoy Tayne Statya 2, (1997). http://pravo.gov.ru/proxy/ips/?docbody=\&nd=102025035, (Erişim Tarihi: 20.03.2017). 